\title{
Overview of the impact of forest habitats quality and landscape disturbances on the ecology and conservation of dormice species
}

\author{
Izabela Fedyń $^{1,2} \cdot$ Tomasz Figarski $^{1} \cdot$ Łukasz Kajtoch $^{1}$ (D)
}

Received: 1 August 2020 / Revised: 20 January 2021 / Accepted: 26 January 2021 / Published online: 14 February 2021

(c) The Author(s) 2021

\begin{abstract}
Arboreal mammals are a group of special concern. We reviewed the available literature to summarize the overall potential effects of forest habitat disturbances on dormice ecology and population parameters. We took into consideration the influence of forest structure, area size and fragmentation, vegetation biodiversity, forestry treatments, and the development of road networks. The vast majority of studies have only examined two species, hazel and edible dormouse, while the ecological requirements and conservation priorities of forest, garden, and Japanese dormice have rarely been studied. There has been a substantial increase in the number of dormice studies; however, many aspects of their ecology are still unknown. The current state of knowledge points to the essential role of the complex vertical structure of forest vegetation in providing arboreal movement corridors and safe nesting places for dormice species. Moreover, dormice species are cavity dwellers that depend on the presence of old trees and nest boxes, which could have ambiguous effects.
\end{abstract}

Keywords Arboreal rodents · Forest management $\cdot$ Glis glis $\cdot$ Gliridae $\cdot$ Habitat fragmentation $\cdot$ Muscardinus avellanarius

\section{Introduction}

Recently published data indicate that only $24 \%$ of global tree cover is intact forests (Global Forest Watch 2002), while remaining forests are under permanent or temporary conversion. The majority of them (73\%) are under temporary disturbances factors, including forestry, shifting agriculture, or wildfires. This pattern is spatially diverse, for example, in Europe $95 \%$ of forest conversion is by forestry, while in South Asia and Latin America the major driver of forest disturbance is deforestation (Curtis et al. 2018).

Four Eurasian species (edible dormouse Glis glis, forest dormouse Dryomys nitedula, garden dormouse Eliomys quercinus, hazel dormouse Muscardinus avellanarius) are

Communicated by Claus Bässler.

Łukasz Kajtoch

lukasz.kajtoch@gmail.com

1 Institute of Systematics and Evolution of Animals, Polish Academy of Sciences, Sławkowska 17, 31-016 Kraków, Poland

2 Department of Forest Biodiversity, Faculty of Forestry, University of Agriculture, al. 29 Listopada 46,

31-425 Kraków, Poland forest animals and are essential elements of forest ecosystems. They act as an additional source of food for some predatory mammals and birds, including protected species as Eurasian lynx Lynx lynx, Eagle owl Bubo bubo or Ural owl Strix uralensis (Marchesi et al. 2002; Krofel et al. 2011; Obuch et al. 2013) and Tawny owl Strix aluco (Marchesi et al. 2006). Moreover, as cavity dwellers, some of them are known to be competitors with hole-nesting songbirds having a significant influence on their reproductive success (Sarà et al. 2005; Juškaitis 2006; Adamík and Král 2008). Dormice, as with other forest rodents, are likely to be important consumers and vectors of fungi (Schickmann et al. 2012) and plants (Juškaitis 2007b).

European dormice have wide ranges (IUCN 2020), but records are often dispersed with numerous gaps, which reflect that they are rare in many parts of their ranges and/or there is a gap in knowledge (Kryŝtufek and Vohralik 1994; Mitchell-Jones et al. 1999; Bertolino 2017; Juškaitis 2018). They are protected both in local, national, and international scales. Of the 29 species of Gliridae, 15 of them are listed as least concern, one as near threatened, and two as vulnerable on the IUCN Red List. For the other 11 species, there is insufficient data (DD category-data deficient) because they are poorly known. Despite the fact that some of them are relatively common across its range, local populations can be 
threatened and isolated (Juškaitis 2018). Some populations decline despite strict protection, conservation actions, and monitoring programs (Bright and Morris 1996; Orlov et al. 2013; Goodwin et al. 2017). It indicates a high influence of local anthropogenic changes on conservation status. Habitat loss, fragmentation, and improper forest management are distinguished as crucial factors (Jurczyszyn 1997; Mortelliti et al. 2011; Fietz et al. 2014; Dondina et al. 2016; Juškaitis 2018). Forest-dependent dormice are highly exposed to modification of forests, both for landscape as well as stand scale (e.g., deforestation and character of remaining ecosystems management and their protective regime). There are several issues that can have crucial effects on dormice habitat quality, but current knowledge of significance of forest habitat alteration is limited. Due to the fact that many dormice species are associated with forests, the knowledge of forest management in terms of the details and alteration of woody habitats is crucial for optimizing the conservation and development of guidelines for sustainable forest management.

The aim of this review is to summarize the current state of knowledge of the impact of habitat quality and anthropogenic transformations (particularly these related with forestry and landscape disturbances) on ecology and conservation of arboreal Gliridae.

\section{Methods}

\section{Search strategy}

To identify species of interest, we performed an advanced search in IUCN Red List with filters: "Gliridae" in taxonomy and "forest" in habitats. We distinguished six representative genera: Dryomys, Eliomys, Glirulus, Glis, Graphiurus, Muscardinus, which were considered to include in our review. Myomimus roachi was omitted as this species is not forestdweller (Peshev et al. 2004; Nedyalkov et al. 2018). Also, Chaetocauda was not included as this species is known only from five specimens (Holden-Musser et al. 2016).

We searched the literature with Web of Science (www. webofknowledge.com) and Scopus (https://www.scopu s.com/). The following terms were used for search strategy: ("gliridae" OR "glis" OR "muscardinus" OR "eliomys" OR "dryomys" OR "graphiurus" OR "glirulus" OR "dormice" OR "dormouse") AND ("forest" OR "habitat" OR "forest management" OR "ecology" OR "woodland" OR "coppice" OR "landscape"). The adopted strategy of search followed the Transparent Reporting of Systematic Reviews and Meta-Analyses (http://www.prisma-statement.org/), which is standard for systematic reviews and meta-analyses. We selected Web of Science and Scopus as they are the two most widespread and comprehensive international databases of literature. We intentionally omitted articles published in local journals (regardless of the language) if these papers had not appeared in the search. Finally, only papers in English were included in our review as both databases are valid only with respect to English journals. Some of the important articles from local journals have been used for the discussion, but not included in the analyses (that was based on only articles found in the search and which were not excluded based on the criteria listed below). This concerns mostly reviews papers and studies summarizing information about dormice populations from particular countries (e.g., Jurczyszyn 1997, 2001; Gatter and Schütt 2001; Verbeylen 2006; Lang et al. 2013; Büchner and Lang 2014).

The search was done at 14.02.2020 and included only papers published until 2019. During the initial search, each result was verified whether it was unique (all doublets were removed) and next examined for whether or not it concerned the topic. Papers that had no relevance were excluded, for the following reasons: 1) papers not related with the topic of research, 2) papers about forest or ecology, but referred to other systematic group than dormice, 3) articles about dormice, but with no direct relation with forest. Finally, two sets of databases were confronted to again remove all repeated publications.

\section{General characterization of studies}

We evaluated qualified papers to determine the scope and progress of studies. We reviewed them with respect to i) temporal (year) and spatial (country) characteristics of publications, ii) species, iii) used tools and methods, iv) what aspects of ecology and biology were subject of interest, v) what aspects of habitat and forest management were included.

In the review phase, only edible dormouse, forest dormouse, garden dormouse, hazel dormouse and Japanese dormouse were taken considered due to insufficient data concerning Graphiurus spp.

\section{Issues selected for review phase}

For the purposes of review, we examined the collected papers on the following aspects of forest disturbances and their relation to dormice ecology and conservation:

1. Forest area size and continuity

2. Existence of movement barriers

3. Silvicultural treatments

4. Vertical and spatial forest structure

5. Old trees and tree microhabitats abundance

6. Plant diversity 


\section{Characterization of dormice studies: literature summary}

\section{PRISMA search outputs}

Our search produced 1219 results (346 in WoS and 873 in Scopus). Through this search, we identified 67 articles relating to dormice and forest management, which means that only 7.7\% of the articles in Scopus and 19.4\% in the Web of Science satisfied the inclusion criteria. The remaining papers were excluded in the assessment stage (Fig. 1).

\section{General overview}

The majority of articles included to our review $(76 \%, \mathrm{n}=51)$ were published after 2005 (Fig. 2; Supplementary Table 1); the greatest number of the publications were noted in last decade $(57 \%, \mathrm{n}=38)$. The increase in the number of published records was moderate $(\mathrm{Rho}=0.51)$. Most of the studies were conducted in Italy, the United Kingdom, Lithuania and Germany (Table 1). One to three records refer to remaining 17 European countries. Only two studies refer to dormice from Asia (Japan).

The selected set of publications refers to studies of only five species: forest dormouse, garden dormouse, edible dormouse, hazel dormouse from Europe and Japanese dormouse from Japan (Supplementary Table 1). The search failed to identify any relevant study on Graphiurus genus. The majority of studies examined only two species: $66 \%$ studied hazel dormouse; $25 \%$ studied edible dormouse (Fig. 3). Few papers referred to more than one species: two to hazel and edible dormouse; one to hazel, edible and forest dormouse. Additionally, three articles also concerned Red squirrel Sciurus vulgaris; two-wood mice Apodemus sylvaticus; and one each to European badger Meles meles, Algerian mouse Mus spretus, white-toothed shrew Crocidura russula, common shrew Sorex araneus, bank vole Myodes glareolus, and harvest mice Micromys minutus.

The most common tool used in the study of the dormiceforest/habitat relation was nest boxes $(56 \%, \mathrm{n}=38)$. Other tools were focused on the direct detection of individuals or
Table 1 Number of publications about dormice — habitat/forestry relation among countries

\begin{tabular}{|c|c|c|c|c|c|c|}
\hline \multirow[t]{2}{*}{ Country } & \multicolumn{6}{|c|}{ Number of records } \\
\hline & Total & D. nitedula & E. quercinus & G. japonicus & G. glis & M. avellanarius \\
\hline Bosnia and Hercegovina & 1 & $*$ & ? & - & 1 & * \\
\hline Coartia & 1 & $*$ & $*$ & - & 1 & * \\
\hline Denmark & 1 & - & - & - & 1 & $*$ \\
\hline France & 1 & - & $*$ & - & 1 & $*$ \\
\hline Lativia & 1 & $*$ & $*$ & - & 1 & * \\
\hline Macedonia & 1 & $*$ & - & - & 1 & $*$ \\
\hline Netherlands & 1 & - & $*$ & - & - & 1 \\
\hline Slovenia & 1 & $*$ & $*$ & - & 1 & $*$ \\
\hline Turkey & 1 & $*$ & - & - & 1 & $*$ \\
\hline Austria & 2 & $*$ & $*$ & - & 2 & $*$ \\
\hline Czech Republic & 1 & $*$ & $*$ & - & 1 & $*$ \\
\hline Hungary & 3 & 2 & - & - & 3 & 2 \\
\hline Poland & 3 & 1 & $*$ & - & 2 & $*$ \\
\hline Russia & 3 & 1 & $*$ & - & 2 & $*$ \\
\hline Spain & 3 & - & 2 & - & 1 & - \\
\hline Sweden & 3 & - & - & - & - & 3 \\
\hline Germany & 9 & $*$ & $*$ & - & 5 & 4 \\
\hline Lithuania & 9 & 1 & - & - & 2 & 7 \\
\hline United Kingdom & 16 & - & - & - & 1 & 15 \\
\hline Italy & 18 & $*$ & 2 & - & 5 & 12 \\
\hline Japan & 2 & - & - & 2 & - & - \\
\hline
\end{tabular}

(*species occurs in the country, but there is no papers about given dormice species and forest/habitat relation, - species doesn't occur in the country, ? not known; data sources on species distribution: Bertolino 2017-garden dormouse, Kryŝtufek, \& Vohralik 2014—forest dormouse, other species-IUCN 2020). Only articles retrieved from "Scopus" (Elsevier) and "Web of Science" (Clarivate Analytics) databases are presented 
Fig. 1 Prisma flow-diagram (see Moher et al. 2009) for literature search for the purposes of this study. Values indicate number of papers excluded at different assessment stage. Only articles retrieved from "Scopus" (Elsevier) and "Web of Science"(Clarivate Analytics) databases are presented

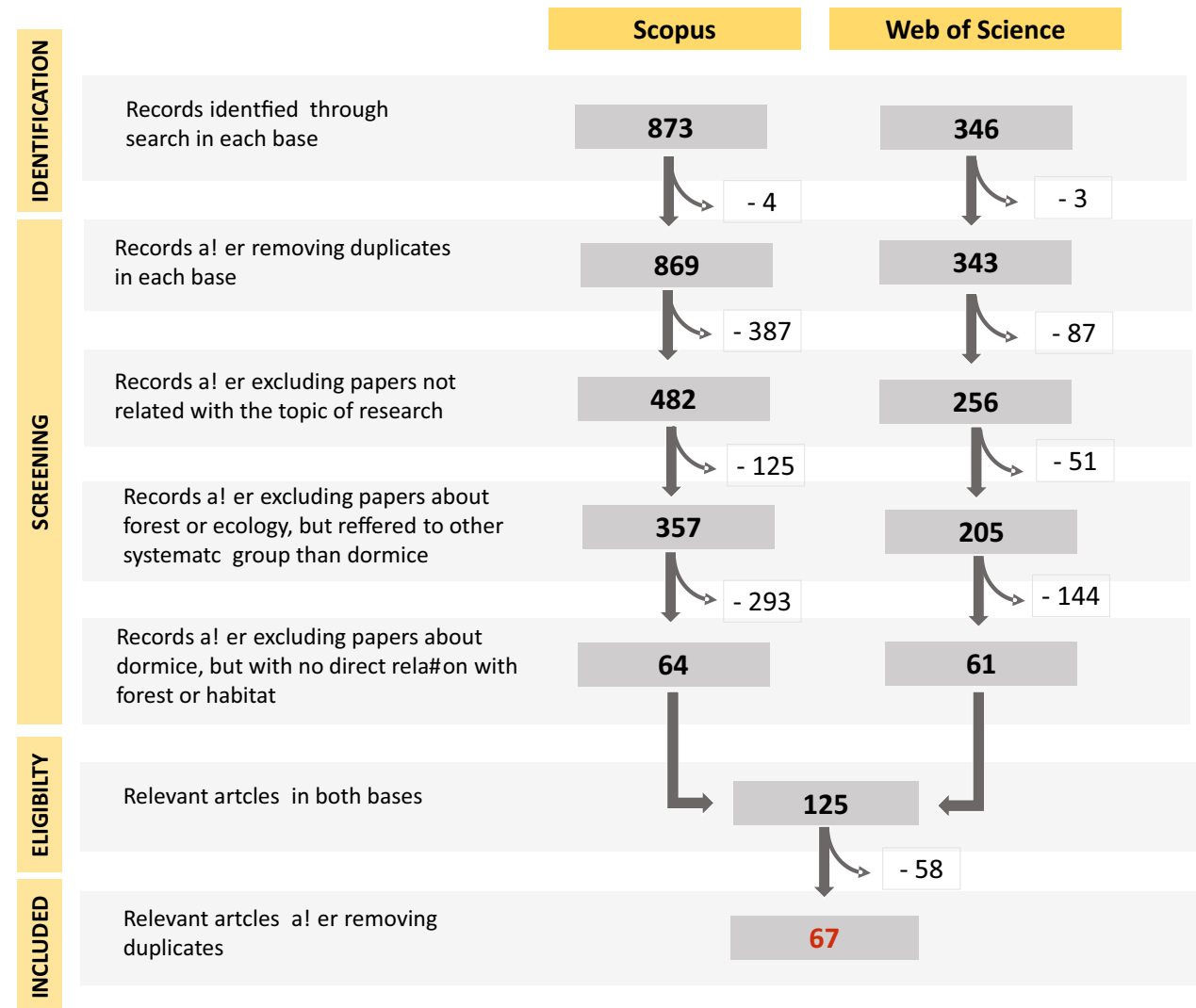

$y=0,005 x 2+0,001 x+0,6517$

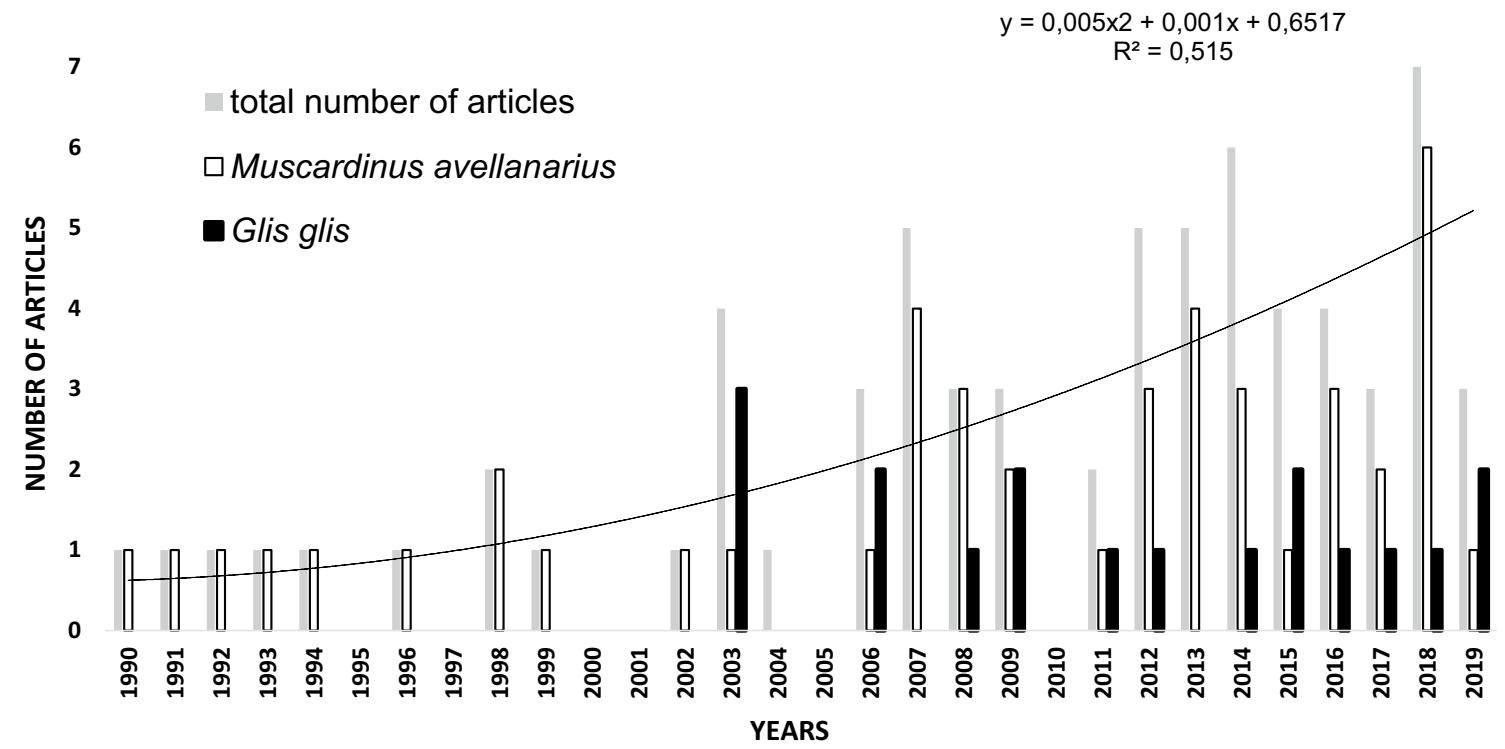

Fig. 2 The number of studies $(\mathrm{n}=67)$ published by a year (together and for two most widely studied species: hazel and edible dormice). Only articles retrieved from "Scopus" (Elsevier) and "Web of Sciences" (clarivate analytics) databases are presented

their signs in the field using classic observations or radiotracking, and some also focused on the collection of digital records or samples (Fig. 4, Supplementary Table 1). Single studies were based on second-hand data (Fig. 4). In 22 (32\%) studies, more than one tool was used.

In these studies, where dormice were captured (with use of nest boxes, live traps or nest tubes; $n=55$ ), animals were 


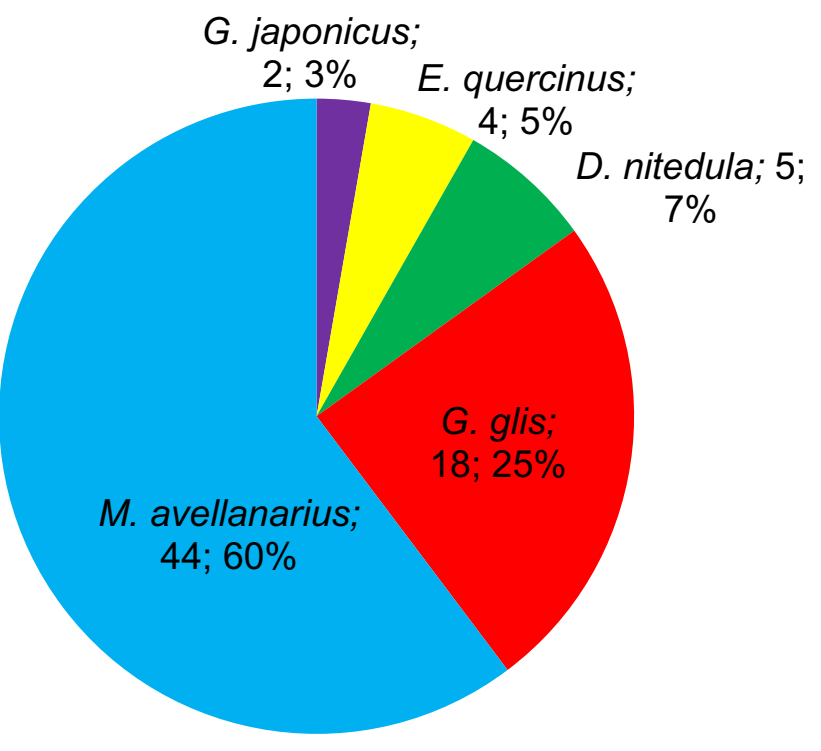

Fig. 3 Numbers and share of publications referring to particular species of dormice. Only articles retrieved from "Scopus" (Elsevier) and "Web of Science" (Clarivate Analytics) databases are presented

usually marked and recaptured $(49 \%, \mathrm{n}=27)$ (Fig. 5, Supplementary Table 1). Other studies in this group of research were done mostly for a determination of occurrence, tracking, sample collection for genetics and estimation of survivor (Fig. 5).

Most of the studies related with dormice and their habitat quality or disturbance concerned the hazel and edible dormouse (Supplementary Table 1, Table 2). Such investigations have rarely been conducted in the case of forest, garden and Japanese dormouse.

\section{Relationships between forest habitat disturbances and dormice ecology}

\section{Landscape level}

\section{Forest area size and continuity}

Data referring to this issue are available only for hazel and edible dormice.

The distribution of edible dormouse is determined by the availability of large, mature (Marteau and Sarà 2015), and isolated woodlands (Capizzi et al. 2003). Dispersal of this species is closely linked to forest continuity, and fragmentation results in limited gene flow, low genetic diversity, and differences in demography and body size (Fietz and WeisDootz 2012; Fietz et al. 2014; Herdegen et al. 2016; Moska et al. 2018; Michaux et al. 2019). Edible dormouse, which is more sensitive than hazel dormouse to decreased patch size and increased fragmentation (Mortelliti et al. 2009), have been found in areas measuring as small as approximately 6 ha, but their highest probability of occurrence was found in woodlots of $40-50$ ha in area or greater (Capizzi et al. 2003). According to the previously mentioned authors, the size of wooded area proved even more important than isolation in predicting the presence or absence of this dormouse species. Also, a population genetics study by Fietz et al. (2014) indicated that edible dormouse populations from small and fragmented forests are genetically isolated and are more unstable over time.

Hazel dormouse occurrence is also dependent upon forest area and isolation (Bright et al. 1994; Capizzi et al. 2003; Mortelliti et al. 2011; Dietz et al. 2018). The colonization

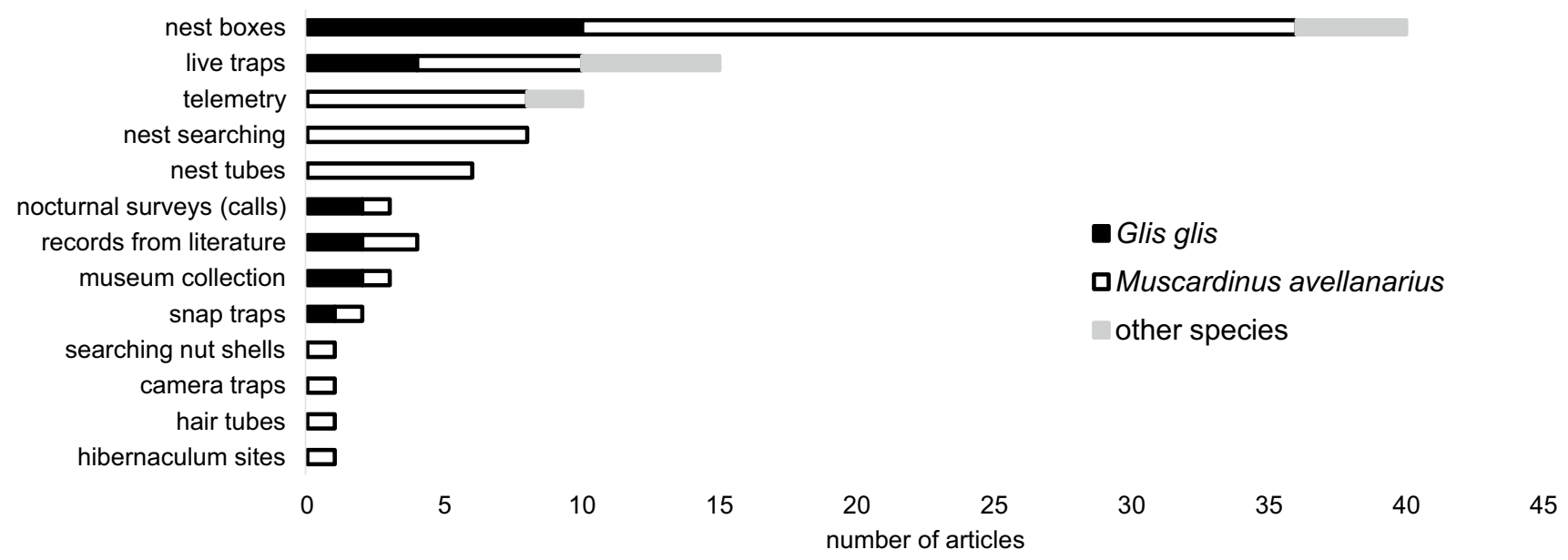

Fig. 4 Tools used in studies of relations between dormice and their habitats or forestry (presented for two most widely studied species: hazel and edible dormice and other taxa together). Only articles retrieved from "Scopus" (Elsevier) and "Web of Science" (Clarivate Analytics) databases are presented 


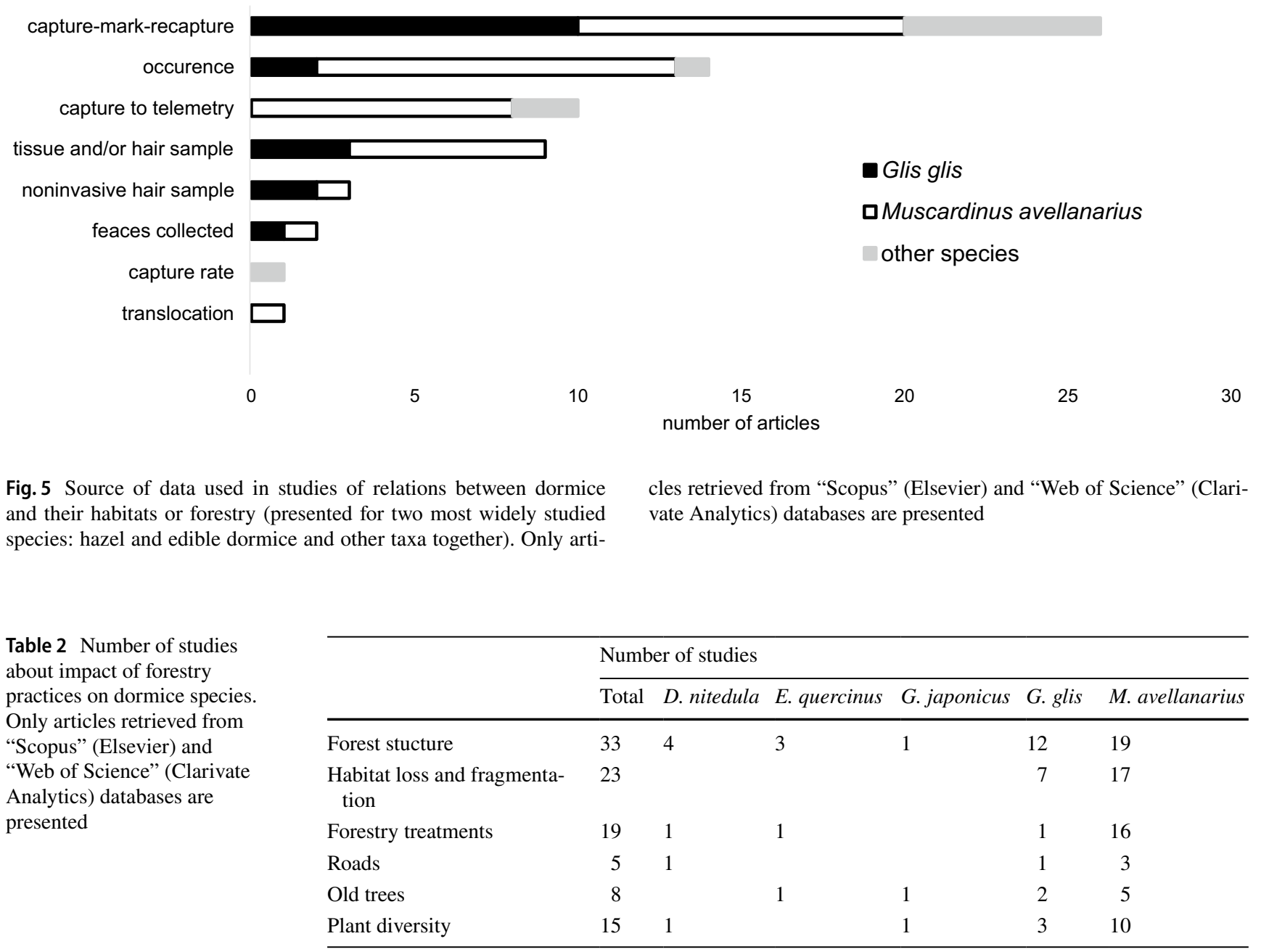

and extinction probability of the hazel dormouse are driven by the distance between habitat patches and the presence of hedgerows that connect and enhance movement between forest patches (Iannarilli et al. 2017), but only in landscapes where forest cover is higher than 5-10\%. In areas with lower forest cover, tree lines are ineffective (Mortelliti et al. 2011; Dondina et al. 2016). Hazel dormouse is considered a sedentary species, with strong female philopatry-the effects of isolation by distance were observed even within a scale of $1 \mathrm{~km}$ (Naim et al. 2014). For example, the hazel dormouse prefers to move in longer arboreal routes, as opposed to shorter routes across open land (Bright and Morris 1991; Bright 1998). Over open ground, the hazel dormouse can migrate across distances ranging from approximately 100-500 m (or up to $670 \mathrm{~m}$ ) (Büchner 2008; Keckel et al. 2012; Mortelliti et al. 2013), and more than $1200 \mathrm{~m}$ over forested areas (Juškaitis 1997). Subpopulations in fragmented landscapes are characterized by low numbers of migrants compared to continuous landscapes (Bani et al. 2018). As a result, the spatial separation of suitable habitats has an impact on the genetic isolation of species subpopulations
(Naim et al. 2012; Bani et al. 2017), which negatively influences population stability. Patch size has a crucial effect on local extinction, and, in consequence, population persistence, independent of habitat quality (despite the availability of resources) (Mortelliti et al. 2014). The incidence of dormice increases in wooded areas greater than 20 ha, but only slightly in larger areas. This suggests that 20 ha is the minimum patch size required for the survival of hazel dormouse populations (Bright et al. 1994); however, reproduction events were also found in coppices smaller than 2 ha (Capizzi et al. 2002; Büchner 2008). The survival of hazel dormice in the smallest wooded patches depends upon the presence of hedgerows that connect woodlots or upon the presence of other woodlots less than $20 \mathrm{~m}$ away (Bright et al. 1994; Keckel et al. 2012).

\section{Existence of movement barriers}

At a small spatial scale, linear gaps in vegetation can limit the arboreal movement of dormice. Linear gaps in forests 
are created mainly by networks of tracks including roads, railways, and, to a lesser extent, major compartment lines.

Forest and edible dormice avoid gaps in forest stands because they inhibit movement in the canopies (Juškaitis and Šiožinytė 2008; Juškaitis et al. 2012; Magomedov 2015), but edible dormice can occasionally travel short distances across open areas (Bieber 1995; Bieber and Ruf 2009). If there is no arboreal connection, the hazel dormouse can cross roads relatively often (Chanin and Gubert 2012; Kelm et al. 2015). The hazel dormouse can even cross major roads and use roadside shrub vegetation as suitable habitat. As a result, roads do not cause physical and genetic isolation of subpopulations (Friebe et al. 2018). Additionally, connection between habitats fragmented by linear barriers can be enhanced by arboreal bridges (White and Hughes 2019).

\section{Stand level}

\section{Vertical and spatial structure}

Forest structure is an important variable in the habitat selection of probably all dormice species; however, the data available for dormice vary greatly among species. Dormice prefer to move along thin and horizontal branches (see Youlatos et al. 2015 for Graphiurus), but particular species are able to move on branches of different thickness (e.g., $2 \mathrm{~mm}$ for hazel dormouse, more than $5 \mathrm{~mm}$ for edible dormouse; Karantanis et al. 2017). Vertical stratification and structural continuity of vegetation ensures many arboreal routes for dormice by means of complex branch connections that facilitate movement and likely reduces predation risk (Bright and Morris 1996; Magomedov 2015; Cornils et al. 2017). Connectivity between understory and canopy layers (Bright and Morris 1996), as well as within a single layer (canopy or understory), were found to be important (Juškaitis and Šiožinytė 2008).

A well-developed and dense understory stratum is an important variable in characterizing forest dormouse nest sites (Juškaitis et al. 2012); therefore, this species is more abundant in habitats with dense shrub vegetation (Magomedov 2015). According to Pilāts et al. (2012) this species prefers mature forest stands with a rich shrub layer and forest edges.

The garden dormouse occupies forests, woodlands, rock crevices, orchards and human dwellings (Holden-Musser et al. 2016). In mountain regions it is known to prefer rocky areas characterized by a thick shrub layer and low canopy closure (Bertolino 2007). This is a species which travels mainly on the ground, while the shrub layer provides food and shelter (Bertolino et al. 2003).

Cornils et al. (2017) reported that canopy closure created suitable habitat for the edible dormouse, which experienced limited locomotion in the presence of thinner branches (this rodent failed to move on 2-5 mm twigs; Karantanis et al. 2017). Age of forest stand has no significant importance for edible dormouse (Juškaitis and Šiožinytė 2008).

The hazel dormouse, similar to the forest dormouse, selects for nesting sites in forests with a well-developed and dense understory stratum (Panchetti et al. 2007), especially when the nest tree is well connected with the surrounding vegetation (Juškaitis et al. 2013). In hedgerows, hazel dormice select nesting places in dense, often thorny, vegetation such as blackthorn, bramble, and field rose (Wolton 2009). Due to their dense vegetation structure, young Norway spruce (Picea abies) plantations can also provide suitable nesting site habitat for the hazel dormouse, but this rodent avoids pure pine stands without an understory layer (Juškaitis 2007a). Shading significantly reduces the productivity of understory and forest floor species. Flowers and fruits are an important part of the dormice diet (Bright and Morris 1993), thus stands characterized by a closing canopy and shaded understory are avoided by the hazel dormouse (Berg 1996; Bright and Morris 1996; Juškaitis and Šiožinytė 2008). Mature and naturally thinned out stands create habitats suitable for hazel dormouse through gap dynamics and understory development (Juškaitis and Šiožinytė 2008). Likewise, stands with clumped canopies, which create a mosaic of closing canopies and gaps, provide favorable habitats for the hazel dormouse (Williams et al. 2013).

\section{Old trees and tree microhabitats abundance}

All arboreal dormice species are naturally cavity dwellershowever, hazel dormice can live in forests without cavities by building nests in bushes, and edible, garden, forest and Japanese dormice can also utilize the ground surface and rocky cavities (Scaravelli and Bassi 1994; Shibata 2004; Juškaitis and Remeisis 2007b; Figarski 2009; HoldenMusser et al. 2016). Therefore, the presence of older trees with arboreal microhabitats (tree holes, decaying wood, cracked bark) was found to be a necessary element of forest ecosystems for these arboreal rodents, and nest site abundance is a known limiting factor for dormouse population growth (i.e., hazel dormouse; Juškaitis 2005). Tree cavities and hollows are one of the most frequently used nest and rest sites of the hazel, edible, Japanese, and forest dormouse (Bright and Morris 1992; Shibata et al. 2004; Juškaitis 2005; Ściński and Borowski 2006). The garden dormouse is also associated with old-growth forests (Arnan et al. 2014). In some managed forests, hazel dormice may chose nest boxes more frequently than natural cavities (Bright and Morris 1992; Juškaitis 2005).

According to Moreno and Rouco (2013), the garden dormouse may be more abundant in burned areas in old-growth 
forests, as fire creates important microhabitats, but this observation requires further studies.

The low usage of nest boxes by edible dormouse in mature stands with high proportions of hollow trees (Juškaitis and Siozinyte 2008; Iwińska et al. 2020) may be due to a preference for natural hollows.

\section{Plant diversity}

Species diversity ensures a continuum of different food resources among seasons (Bright and Morris 1993; Juškaitis et al. 2013).

Japanese dormice preferred next boxes located in areas with high numbers of shrubs and trees that provided different types of food throughout the seasons (flowers, fruits, seeds) (Nakamura-Kojo et al. 2014).

For the forest dormouse, the number of shrub species and understory cover has an important impact on this species' choice of nest sites (Juškaitis et al 2012).

Beech and oak trees are essential components of edible dormice habitats (Hecker et al. 2003; Milazzo et al. 2003; Juškaitis and Augutė 2015). Edible dormouse reproduction is dependent upon masting years, when the availability of beech or oak seeds is high (Ruf et al. 2006; Bieber and Ruf 2009; Vekhnik 2019). In masting years, the presence of mature beach and oak trees can increase local food availability. Therefore, the proportion of reproducing female of edible dormouse increases during mast years; however, this effect is important only in younger stands. In mature managed forests, an increase in tree age does not seem to be crucial for dormice populations (Lebl et al. 2011). However, a high proportion of one tree species in a stand (i.e., beech) is unfavorable for edible dormouse (Milazzo et al. 2003; Cornils et al. 2017) because in low mast years there are no alternative food resources. Heterogeneous habitats consisting of bushes and young trees provide more constant but less energetic food than forests dominated by beech, which results in lower reproductive output but higher survival probability in edible dormouse (Bieber and Ruf 2009).

The hazel dormouse consumes food resources depending on their availability in space and time (Juškaitis et al. 2016). Understory and canopy species diversity is related to hazel dormouse abundance, especially those species producing soft mast (e.g., wayfaring tree Viburnum lantana, blackthorn Prunus spinosa), flowers, fruits, and seeds (Bright and Morris 1990; Goodwin et al. 2018). This diversity also enhances the individual survival of hazel dormouse and the probability of colonization (and population establishment) of a habitat patch (Mortelliti et al. 2014). Moreover, shrub diversity and cover have an important impact on nest site choice by hazel dormice (Berg and Berg 1998; Wolton 2009; Juškaitis et al. 2013). On the other hand, due to their dense structure, young, single-species conifer and deciduous plantations can be successfully inhabited by hazel dormouse (Berg and Berg 1999; Bako and Hecker 2006; Juškaitis 2007a).

\section{Silvicultural treatments}

Silvicultural treatments result in temporal changes in the structure and species composition of vegetation. Data related to the impact of forest treatments are available mostly for hazel and edible dormouse. These species generally react differently due to their distinct habitat requirements. Treatments have negative temporal effects on dormice density (Juškaitis 2008). Clear-cutting has radical effects on vegetation structure, and, subsequently, on arboreal mammals by modifying their topical and trophic conditions due to the complete removal of nearly all canopy cover. Initially, a clear-cut habitat with abundant ground cover improves conditions for many ground-dwelling small mammals, but the arboreal activity of small mammals has been eliminated (Gurnell et al. 1992).

The forest dormouse avoids nest sites situated in areas with gaps in vegetation (e.g., tree stumps), but successfully occupies overgrown clearings in which dense vegetation creates suitable habitat (Juškaitis et al. 2012).

The edible dormouse locomotes mainly in the canopy stratum; thus, every gap in the canopy due to stand thinning negatively affects its occurrence (Juškaitis and Šiožinytė 2008). Stands with tall trees and a low stem number were more important variables compared to quantitative tree structure (Capizzi et al. 2003). Therefore, the edible dormouse occurs more frequently in tall (i.e., mature) forests or coppices with a long rotation cycle than in areas with frequent and large-scale treatments (e.g., felling of the whole forest fragment, short-time coppicing) (Capizzi et al. 2003). The negative impact of coppicing was indicated when a short rotation cycle had been applied. The authors did not record any sign of edible dormouse presence in coppices with rotation cycle shorter than 18 years.

Among dormice species, the hazel dormouse appears to be the most generalist in terms of habitat-it occupies both coppice forests (with dense understory and some taller, older trees) and tall forest stands (Bright and Morris 1990; Juškaitis and Šiožinyte 2008; Zapponi et al. 2013; Sozio et al. 2016), due to dense, complex vegetation structure. Clear-cuts and coppices provide successional stages of woody vegetation that are known to be the best habitat for hazel dormouse (Berg 1996; Bright and Morris 1996; Juškaitis 2007a; Juškaitis and Remeisis 2007a), but only after a few or several years of clearing (Juškaitis 2008, 2020; Sozio et al. 2016). Young trees provide well-hidden nesting sites (Juškaitis and Remeisis 2007a). Decreasing shrub cover (by clearing, but also by natural succession) results in 
lower hazel dormouse abundance (Berg 1996). After removing the majority of mature trees, the number of hazel dormouse nests increases if the shrub layer is well developed (Ramakers et al. 2014). Different methods of tree thinning (e.g., hand felling using chainsaws, mechanized harvesters, both small and large group fells, and clear-cuts) have no significant impact on hazel dormouse density (Trout et al. 2012). Large group felling has the lowest impact on hazel dormouse, while clear-cutting has the highest impact (the majority of nests were destroyed in clear-cut plots). Nests remained unharmed in surrounding unmanaged areas (Trout et al. 2012). Tree felling resulted in higher occupancy of nest boxes, likely due to the destruction of natural nest sites during forestry operations.

\section{Implications for landscape planning with particular emphasis on forest management}

Because of their arboreal character, dormice are highly exposed to ecosystem disturbances, both at the landscape and site level (Bright et al. 2006). The current distributions of individual dormice species are a consequence of past decisions and types of management. Furthermore, their relatively small dispersion abilities prevent dormice from reinhabiting all areas from which they were ousted, even if environmental conditions became favorable again. At the landscape level, due to socioeconomic development and progressing urbanization, habitat improvement for dormice is difficult and requires the collaboration of many authorities and biologists. In turn, at the forest complex and stand level, where dormice still exist, the type and intensity of forest management is of key importance. We can point to a number of suggestions aimed at improving occurrence conditions for dormice.

\section{Farmland management}

One of the crucial factors concerning farmlands is their management, which is reflected in the debate between landsparing and land-sharing concepts (Tscharntke et al. 2012).

Monocultures planted on large areas make the landscape more homogeneous, which is unfavorable for the movements of forest-dependent species. This is one of the most important factors of isolation and degradation (often leading to extinction) of less mobile forest species such as dormice. On the other hand, the wildlife-friendly concept (land-sharing) allows for diversified forming of agricultural production areas where there is space for other types of landscape features such as hedgerows and islets. This can counteract forested-land separation and improve ecosystem services in agricultural landscapes (Navarro and Pereira 2015). It was highlighted that increased connectivity between specific habitats (forested ones in this case) facilitates immigration and counteracts possible extinctions in spared habitats (Grass et al. 2019). Taking action to protect dormice fits this concept well. Projects such as this are undertaken, for instance, in Britain to protect hazel dormouse (Bright et al. 2006). Hedgerows and woodlots should be created from native tree and shrub species and form a kind of coherent network with forests. It is crucial to know the actual distribution of dormice species and areas around forests where dormice still exist. These factors should be taken into consideration in the first place.

\section{Roads, highways and railways}

One of the major threats to dormice populations is fragmentation and isolation by public communication routes (Chanin and Gubert 2012). There are some solutions to mitigate this problem, such as building landscape bridges and overpasses above roads, which can reduce their barrier effect (Minato et al. 2012; White and Hughes 2019). Also translocation of individuals has been adopted (Downs et al. 2020).

\section{Restitution programs}

In most cases, dormice are unable to colonize forested areas, even if environmental conditions are now favorable, due to their low dispersion abilities. The only solution is to relocate some animals from large and healthy natural populations or to use captively bred animals. This kind of conservation program has successfully been undertaken in Great Britain (Bright and Morris1994; Mitchell-Jones and White 2009) and Poland (Jurczyszyn 2001, 2006). It is important to endeavor to translocate individuals from adjacent areas and avoid the use of rodents from other geographical regions and different genetic units (such knowledge is, however, still sufficient only for some local populations) (e.g., Gornung et al. 2010; Fietz et al. 2014; Bani et al. 2018; Michaux et al. 2019). Also, this rule should not be neglected in areas with no local populations, as it could have future consequences in case connectivity among populations in the area is restored (restituted and native).

\section{Forest management}

For existing populations of dormice, which are forestdependent species, current forest management is of special importance.

\section{Forest units}

First of all, we should consider scale as a point of focus. In small, isolated forests (up to approximately $100 \mathrm{ha}$ ), all 
management activities have to be undertaken carefully with particular care taken for each forest stand (forest management unit). Populations of dormice in such a small ecosystems contain fewer individuals and are vulnerable to all kinds of disturbances, both natural and anthropogenic. In large, continuous forests, the conservation approach should be a bit different. In big forest complexes, a complete dormice inventory over the whole area poses organizational and financial difficulties. This applies in particular to more secretive species (such as forest or garden dormouse) and diversified forest ecosystems with a high level of naturalness (e.g., mountain forests). In these cases, we should take into consideration the whole forest complex, not just a particular stand. The main goal is to implement such forest management rules that allow for the continuous occurrence of dormice at the forest-complex scale.

\section{Silvicultural treatments}

Improper forestry can be a significant problem for dormice. However, it is possible to propose and implement appropriate procedures for forest management that will be harmless to dormice. In areas where dormice are quite abundant, a favorable stand structure is of particular importance. First of all, a high density of tree and bush crowns should be maintained, thereby allowing these mammals to move around. This is also important throughout the life of each stand of younger age classes when thinning is carried out. Special attention should be given to stands reaching their rotational age, when they are felled and renewed.

Most kinds of clear-cutting methods are improper for dormice due to their arboreal character, with the exception of small-scale clear-cutting, which could be favorable for the hazel dormouse (Juškaitis 2020).

According to Figarski (2010), a large-scale shelterwood compartment system used in deciduous (e.g., beech) stands can also force dormice to leave such areas. If the canopy is uniformly opened up over the whole area to improve light conditions and promote tree regeneration, it makes dormice movement impossible. This is more harmful for the edible dormouse (related to the overstory to a large extent) than for the hazel dormouse, which can benefit from a welldeveloped understory. For the above reasons, it would be desirable to use more complex cutting methods in deciduous stands such as the modified form of the shelterwood group system. It can be based on selective cuttings (like in a typical shelterwood method) but performed on irregular small areas (up to $0.5 \mathrm{ha}$ ) which successively fill the renewed stand area in a relatively long regeneration period. In this scenario, dormice would have a chance to survive in patches not yet renewed or in those where natural regeneration has already strengthened. Filling the area with fragments of stands of different ages would also enable dormice movement and allow for inhabiting neighboring areas. Another advantage of such proceedings is the ability to create multi-species stands which are more beneficial for dormice because of diversification of their food base (Gatter and Schütt 2001). This is important in low-mast years of beech or oak (Lebl et al. 2011).

In mixed forests with significant amounts of fir, spruce, beech, and oak, which are sometimes the most rich stands in terms of dormice species (settled at least by edible, forest, and hazel dormice in a single forest complex), irregular shelterwood methods with long regeneration periods and based on various types of cuttings seems to be the most appropriate type of forest management (Figarski 2010; Iwińska et al. 2020). In turn, stands dominated by fir should be managed in selection of a system with the longest possible renewal period and be based on single-tree or small-area group cuttings. These types of forest treatments allow one to maintain or shape a large forest mosaic by shaping multi-story, uneven-aged stands whose structure, through well-developed lower forest layers, are a very valuable habitat for dormice (Gatter and Schütt 2001; Iwińska et al. 2020).

Sometimes dormice (e.g., edible dormouse) inhabit less typical forests having high proportions of Scots pine (Pinus sylvestris) and admixtures of oaks and fir. In such forests, the main habitat factor that makes dormice occurrence possible is a well-developed understory of hornbeam and hazel (Iwińska et al. 2020). These forests are managed with the help of various types of group cuttings aimed at increasing the proportion of oak instead of pine. This procedure is favorable for dormice in the long term; however, it has to be stressed that a well-developed understory composed of hornbeam should not be completely cutoff during the harvesting of pines, but instead should be partially included in the future stands (Figarski 2010). According to Iwińska et al. (2020), in such stands most of the daily roosts of edible dormouse are of natural origin, mainly in birches and oak trees. Dead trees or those in poor condition are preferred. These roosting sites are often surrounded by dense vegetation composed of young deciduous trees. That is why preservation of old deciduous trees and a dense understory layer in mixed forests is said to be crucial for arboreal rodents.

Furthermore, in mature stands, managed and well-developed forest edges characterized by a dense shrub layer may form important habitats for the hazel and forest dormouse (Pilāts et al. 2012; Ramakers et al. 2014; Magomedov 2015). At least $5-10 \%$ of stands making up the forest complex where dormice occur should be excluded from harvesting. As far as possible, these fragments should be large, reaching 10-20 ha (Figarski 2010).

In general, dormice occurrence is said to be positively influenced by enhancing the ecological continuity of ecosystems and by increasing the average age of forests, which 
affects the availability of shelters and food (Gatter and Schütt 2001).

\section{Forest environment quality}

Apart from silviculture, we also have a few suggestions for improving dormouse habitat conditions. To enrich the food base of dormice, more attention should be paid to wild cherry, whose fruits are willingly eaten by dormice (Figarski 2010). This is especially important in the early summertime, when trees such as beech or oak are not yet bearing nuts (Jurczyszyn 2018). It is also important to not remove shrubs that these rodents feed on (e.g., hazel).

Another important element is to leave large groups of old trees that would over time develop into habitat that would support dormice in cutting areas (Gatter and Schütt 2001; Iwińska et al. 2020). Nowadays, forest authorities that are subject to the Forest Stewardship Council (FSC) certification are obligated to leave at least $5 \%$ of the stand area planned for harvesting for natural death and decomposition.

One of the major threats to dormice is an insufficient number of natural hiding places such as cavities. Dormice species, as in other hollow dwellers, depend on the availability of tree cavities. Thus, requirements of dormice can partly overlap with those of a guild of cavity-nesting birds, which are more often used as biodiversity indicators (Mikusiński et al. 2001; Gregory et al. 2008) or even as indicators of the impact of forest management practices on biodiversity (Perry et al. 2018). Since birds are presently the most popular umbrella or flagship species, the most complex conservation measures have been designed for this animal group and could be to some extent postponed for other arboreal animals. Arboreal species of dormice occupy (during breeding) tree holes and other cavities created on trees (e.g., under bark or in rotten wood). An exception is the hazel dormouse, which besides nesting in small cavities can build nests in dense bushes or young trees. Consequently, this group of rodents is dependent on the presence of thicker trees and especially old and dying trees as well as dead wood. Therefore, it is important to protect hollow and old trees.

The lack of natural shelters for these animals can be partly overcome by hanging special nest boxes with hollows facing tree trunks; however, dormice also willingly use nest boxes created for birds. Many studies describe populations of dormice nesting in nest boxes. Consequently, the data regarding the relationships between dormice requirements and forestry may be unclear. Nest boxes can cause a supraoptimal breeding density leading to an ecological trap, as was reported in the case of birds (Mänd et al. 2005). Such nest boxes could be beneficial for dormice populations, but only in the short term if boxes are not cleaned, repaired, or replaced. Moreover, a recent study of Iwińska et al. (2020) proves that dormice prefer to roost in natural cavities even if nest boxes are available (up to $70 \%$ of roost were in cavities). In contrast, the long-term study of Gatter and Schütt (2001) in Germany provided evidence that edible dormouse can steadily increase in number if a large number of nest boxes are available, accompanied by high forest practice, increased food and shelter availability, with increasing age of beech stands. Hanging of nest boxes should not be standard practice in the protection of these rodents; however, it could be applied in heavily transformed woods of insufficient age until their maturity.

Table 3 Recommendation for forestry and landscape activities beneficial for selected dormice species, with the greatest number of studies:

\section{Edible dormouse}

Sustaining large and continuous forest areas (at least 50 ha)

Development of wooded corridors (tree lines) connecting forest patches

Restoration of canopy closure across forest gaps (especially linear gaps) by thicker branches (>5 mm)

Limitation of large-scale treatments (large clear-cutting, felling of trees on large areas, frequent coppicing)

Preserving trees with cavities

Management leading to presence of alternative food resources in oak and beech forests (other species of trees and bushes, particularly these giving fruits or nuts), but without predominance of any tree species

\section{Hazel dormouse}

Sustaining continuous forest areas (at least 20 ha) surrounded by suitable habitats

Development of wooded corridors (hedgerows) connecting forest patches

Preserving trees with cavities

Management leading to understory development and complex vegetation structure

Allowing for development of pioneer fruiting trees and bushes

Avoiding of intensive harvesting destroying hibernation sites 


\section{Conclusions}

Knowledge of the relationships between forestry, land use, and the ecology and conservation of dormice species continues to grow thanks to the increasing number of studies on these arboreal rodents. Dormice deserve further study, as these rodents are not common and are even considered rare and threatened in some countries (they are included in the red lists of threatened animals, or are just protected). Moreover, being dependent on complex forest characteristics (e.g., tree cavities, a continuous canopy layer, diverse tree composition, a dense and multispecies understory, forest area continuity), dormice are known to be indicators of forest habitat quality and are vulnerable to some forest treatments and landscape changes. Numerous issues remain and should be topics for future research, especially as it concerns the species least studied so far (i.e., Japanese, garden, and forest dormice). This systematic review summarizes the current state of knowledge of arboreal dormice (particularly the European species) and lists all described relationships between these rodents with forest treatments and landscape disturbances. This review should be helpful in the proper planning of forest management, forest habitat conservation, and facilitating further research. Table 3 presents key actions that should be implemented in forestry for effective protection of dormice populations.

Supplementary Information The online version contains supplementary material available at https://doi.org/10.1007/s10342-021-01362-3.

Acknowledgements We are grateful to Peter Lešo and two anonymous reviewers for their helpful comments to the previous versions of the manuscript.

Author contributions Conceptualization- $-\mathrm{EK}, \mathrm{IF}, \mathrm{TF}$; Data curationIF; Formal analysis-IF, ŁK; Funding acquisition-not applicable; Investigation-IF; Methodology- ŁK, IF, TF; Project administration-ŁK; Resources-IF, ŁK; Software- ŁK; Supervision- ŁK; Validation-IF, ŁK; Visualization-IF, ŁK; Roles/Writing-original draft-IF, ŁK, TF; Writing — review \& editing—IF, ŁK, TF.

Funding This study was funded by the statutory research of Institute of Systematics and Evolution of Animals PAS.

Availability of data and material All data are available along with the manuscript - any source data will be available on request from the corresponding author.

\section{Compliance with ethical standards}

Conflicts of interest Authors declare no conflicts of interests or competing interests.

Ethics approval The study did not require any special permissions.

Consent to participate All authors contributed to the study conception and design. Material preparation, data collection and analysis were performed by Izabela Fedyń, Tomasz Figarski and Łukasz Kajtoch. The first draft of the manuscript was written by Izabela Fedyń and completed by Tomasz Figarski and Łukasz Kajtoch. All authors refilled and commented on previous versions of the manuscript. All authors read and approved the final manuscript.

Consent for publication All authors agreed for the publication of this manuscript.

Open Access This article is licensed under a Creative Commons Attribution 4.0 International License, which permits use, sharing, adaptation, distribution and reproduction in any medium or format, as long as you give appropriate credit to the original author(s) and the source, provide a link to the Creative Commons licence, and indicate if changes were made. The images or other third party material in this article are included in the article's Creative Commons licence, unless indicated otherwise in a credit line to the material. If material is not included in the article's Creative Commons licence and your intended use is not permitted by statutory regulation or exceeds the permitted use, you will need to obtain permission directly from the copyright holder. To view a copy of this licence, visit http://creativecommons.org/licenses/by/4.0/.

\section{References}

Adamík P, Král M (2008) Nest losses of cavity nesting birds caused by dormice (Gliridae, Rodentia). Acta Theriol 53:185-192. https:// doi.org/10.1007/BF03194251

Arnan X, Comas L, Gracia M, Retana J (2014) Composition and habitat use of small mammals in old-growth mountain forests. J Nat Hist 48:481-494. https://doi.org/10.1080/00222933.2013.800611

Bako B, Hecker K (2006) Factors determining the distribution of coexisting dormouse species (Gliridae, Rodentia). Pol J Ecol 54(3):379-386

Bani L, Orioli V, Pisa G, Fagiani S, Dondina O, Fabbri E, Randi E, Sozio G, Mortelliti A (2017) Population genetic structure and sex-biased dispersal of the hazel dormouse (Muscardinus avellanarius) in a continuous and in a fragmented landscape in central Italy. Conserv Genet 18:261-274. https://doi.org/10.1007/s1059 2-016-0898-2

Bani L, Orioli V, Pisa G, Dondina O, Fagiani S, Fabbri E, Randi E, Mortelliti A, Sozio G (2018) Landscape determinants of genetic differentiation, inbreeding and genetic drift in the hazel dormouse (Muscardinus avellanarius). Conserv Genet 19:283-296. https://doi.org/10.1007/s10592-017-0999-6

Berg L (1996) Small-scale changes in the distribution of the dormouse Muscardinus avellanarius (Rodentia, Myoxidae) in relation to vegetation changes. Mammalia 60:211-216. https ://doi.org/10.1515/mamm.1996.60.2.211

Berg L, Berg § (1998) Nest site selection by the dormouse Muscardinus avellanarius in two different landscapes. Ann Zool Fen 35:115-122

Berg L, Berg $\AA$ (1999) Abundance and survival of the hazel dormouse Muscardinus avellanarius in a temporary shrub habitat: a trapping study. Ann Zool Fen 36:159-165

Bertolino S (2007) Microhabitat use by garden dormice during nocturnal activity. J Zool 272:176-182

Bertolino S (2017) Distribution and status of the declining garden dormouse Eliomys quercinus. Mam Rev 47:133-147. https:// doi.org/10.1111/mam.12087

Bertolino S, Cordero N, Currado I (2003) Home ranges and habitat use of the garden dormouse (Eliomys quercinus) in a mountain habitat in summer. Acta Zool Acade Sci Hung 49:11-18 
Bieber C (1995) Dispersal behaviour of the Edible dormouse (Myoxus glis) in a fragmented landscape in central Germany. Hystrix 6:257-264. https://doi.org/10.4404/hystrix-6.1-2-4037

Bieber C, Ruf T (2009) Habitat differences affect life history tactics of a pulsed resource consumer, the edible dormouse (Glis glis). Pop Eco 51:481. https://doi.org/10.1007/s10144-009-0140-x

Bright PW (1998) Behaviour of specialist species in habitat corridors: arboreal dormice avoid corridor gaps. Anim Behav 56:1485-1490. https://doi.org/10.1006/anbe.1998.0921

Bright PW, Morris PA (1990) Habitat requirements of dormice Muscardinus avellanarius in relation to woodland management in Southwest England. Biol Conserv 54:307-326. https://doi. org/10.1016/0006-3207(90)90143-D

Bright PW, Morris PA (1991) Ranging and nesting behaviour of the dormouse, Muscardinus avellanarius, in diverse low-growing woodland. J Zool 224:177-190. https://doi. org/10.1111/j.1469-7998.1991.tb04797.x

Bright PW, Morris PA (1992) Ranging and nesting behaviour of the dormouse Muscardinus avellanarius, in coppicewith-standards woodland. J Zool 226:589-600. https://doi. org/10.1111/j.1469-7998.1992.tb07502.x

Bright PW, Morris PA (1993) Foraging behaviour of dormice Muscardinus avellanarius in two contrasting habitats. J Zool 230:69-85. https://doi.org/10.1111/J.1469-7998.1993.TB026 73.X

Bright PW, Morris PA (1994) Animal translocation for conservation: performance of dormice in relation to release methods, origin and season. J Appl Ecol 31:699-708. https://doi.org/10.2307/24041 60

Bright PW, Morris PA (1996) Why are dormice rare? A case study in conservation biology. Mam Rev 26:157-187. https://doi. org/10.1111/j.1365-2907.1996.tb00151.x

Bright PW, Mitchell P, Morris PA (1994) Dormouse distribution: survey techniques, insular ecology and selection of sites for conservation. J Appl Ecol. https://doi.org/10.2307/2404547

Bright PW, Morris PA, Mitchell P (2006) The dormouse conservation handbook, 2nd edn. English Nature, Peterborough

Büchner S (2008) Dispersal of common dormice Muscardinus avellanarius in a habitat mosaic. Acta Theriol 53:259-262. https:// doi.org/10.1007/BF03193122

Büchner S, Lang J (2014) Die Haselmaus (Muscardinus avellanarius) in Deutschland-Lebensräume, Schutzmaßnahmen und Forschungsbedarf. Säugetierkundliche Informationen 9:367-377

Capizzi D, Battistini M, Amori G (2002) Analysis of the hazel dormouse, Muscardinus avellanarius, distribution in a Mediterranean fragmented woodland. Ita J Zool 69:25-31. https://doi. org/10.1080/11250000209356434

Capizzi D, Battistini M, Amori G (2003) Effects of habitat fragmentation and forest management on the distribution of the edible dormouse Glis glis. Acta Theriol 48:359-371. https://doi. org/10.1007/BF03194175

Chanin P, Gubert L (2012) Common dormouse (Muscardinus avellanarius) movements in a landscape fragmented by roads. Lutra 55:3-15

Cornils JS, Hoelzl F, Rotter B, Bieber C, Ruf T (2017) Edible dormice (Glis glis) avoid areas with a high density of their preferred food plant-the European beech. Front Zool 14:23. https://doi. org/10.1186/s12983-017-0206-0

Curtis PG, Slay CM, Harris NL, Tyukavina A, Hansen MC (2018) Classifying drivers of global forest loss. Science 361:1108-1111. https://doi.org/10.1126/science.aau3445

Dietz M, Büchner S, Hillen J, Schulz B (2018) A small mammal's map: identifying and improving the large scale and cross border habitat connectivity for the hazel dormouse Muscardinus avellanarius in a fragmented agricultural landscape. Biodivers Conserv 27:1891-1904. https://doi.org/10.1007/s10531-018-1515-0
Dondina O, Kataoka L, Orioli V, Bani L (2016) How to manage hedgerows as effective ecological corridors for mammals: a two-species approach. Agric Ecosyst Environ 231:283-290. https://doi. org/10.1016/j.agee.2016.07.005

Downs NC, Dean M, Wells D, Wouters A (2020) Displacing and translocating hazel dormice (Muscardinus avellanarius) as road development mitigation measures. Mam Commun 6:1-9

Fietz J, Weis-Dootz T (2012) Stranded on an island: consequences of forest fragmentation for body size variations in an arboreal mammal, the edible dormouse (Glis glis). Pop Ecol 54:313-320. https ://doi.org/10.1007/s10144-012-0310-0

Fietz J, Tomiuk J, Loeschcke V, Weis-Dootz T, Segelbacher G (2014) Genetic consequences of forest fragmentation for a highly specialized arboreal mammal-the edible dormouse. PLoS ONE 9(2):e88092. https://doi.org/10.1371/journal.pone.0088092

Figarski T (2009) Przypadek wykorzystywani a nory ziemnej przez koszatkę Dryomys nitedula w trakcie sezonu rozrodczego w Lasach Koneckich. Kulon 14:140-142

Figarski T (2010) Ochrona popielicy (Glis glis L., 1766) a sposób zagospodarowania buczyn w Polsce [Conservaton of fat dormouse (Glis glis L., 1766) and beech forests management in Poland]. Chrońmy Przyr Ojcz 66:39-44

Friebe K, Steffens T, Schulz B, Valqui J, Reck H, Hartl G (2018) The significance of major roads as barriers and their roadside habitats as potential corridors for hazel dormouse migration-a population genetic study. Folia Zool 67:98-109. https://doi.org/10.25225/ fozo.v67.i2.a10.2018

Gatter W, Schütt R (2001) Langzeitpopulationsdynamik des Siebenschläfers Myoxus glis in Baden-Württemberg-Ein Kleinsäuger als Gewinner der heutigen Waldwirtschaft und des gesellschaftlichen Wandels. Jahreshefte der Gesellschaft für Naturkunde in Württemberg 157:181-210

Global Forest Watch, 2002. Global forest watch. World Resources Institute, Washington, DC. http://www.globalforestwatch.org. Accessed March 2002

Goodwin CE, Hodgson DJ, Al-Fulaij N, Bailey S, Langton S, Mcdonald RA (2017) Voluntary recording scheme reveals ongoing decline in the United Kingdom hazel dormouse Muscardinus avellanarius population. Mam Rev 47:183-197. https://doi. org/10.1111/mam.12091

Goodwin CE, Suggitt AJ, Bennie J, Silk MJ, Duffy JP, Al-Fulaij N, Bailey S, Hodgson DJ, McDonald RA (2018) Climate, landscape, habitat, and woodland management associations with hazel dormouse Muscardinus avellanarius population status. Mam Rev 48:209-223. https://doi.org/10.1111/mam.12125

Gornung E, Bizzoco D, Colangelo P, Castiglia R (2010) Comparative cytogenetic and genetic study of two Italian populations of the garden dormouse Eliomys quercinus L. (Sciuromorpha: Gliridae). Ital J Zool 77:137-143. https://doi.org/10.1080/11250 000903304107

Grass I, Loos J, Baensch S, Batáry P, Librán-Embid F, Ficiciyan A, Klaus F, Riechers M, Rosa J, Tiede J (2019) Land-sharing/sparing connectivity landscapes for ecosystem services and biodiversity conservation. People Nat 1:262-272. https://doi. org/10.1002/pan3.21

Gregory RD, Vořišek P, Noble DG, Van Strien A, Klvaňová A, Eaton M, Meyling AWG, Joys A, Foppen RP, Burfield IJ (2008) The generation and use of bird population indicators in Europe. Bird Conserv Int 18:S223-S244. https://doi.org/10.1017/S095927090 8000312

Gurnell J, Hicks M, Whitbread S (1992) The effects of coppice management on small mammal populations. In: Ecology and management of coppice woodlands. Springer, pp 213-232

Hecker K, Bako B, Csorba G (2003) Distribution ecology of the Hungarian dormouse species, based on the national biodiversity monitoring system. Acta Zool Acad Sci Hun 49:45-54 
Herdegen M, Radwan J, Sobczynska U, Dabert M, Konjević D, Schlichter J, Jurczyszyn M (2016) Population structure of edible dormouse in Poland: the role of habitat fragmentation and implications for conservation. J Zool 298:217-224. https://doi. org/10.1111/jzo.12304

Holden-Musser ME, Juškaitis R, Musser GM (2016) Gliridae. In: Wilson DE, Lacher TE, Mittermeier RA (eds) Handbook of the mammals of the world-volume 6. lagomorphs and Rodents I. andbook of the mammals of the world-volume 6. Lynx Editions, pp 838-889

Iannarilli F, Melcore I, Sozio G, Roviani D, Mortelliti A (2017) Longterm colonization and extinction patterns of a forest-dependent rodent (Muscardinus avellanarius) in highly fragmented landscapes. Hystrix. https://doi.org/10.4404/HYSTRIX-28.1-11886

IUCN (2020) The IUCN red list of threatened species. Version 2020-1

Iwińska K, Boratyński JS, Trivedi A, Borowski Z (2020) Daily roost utilization by edible dormouse in a managed pine-dominated forest. For Ecol Manag 468:118172

Jurczyszyn M (1997) Wpływ gospodarki leśnej na wyginiecie popielicy, Myoxus glis [L.] w północno-zachodniej Polsce. Badania Fizjograficzne nad Polską Zachodnią Seria C: Zoologia 44:71-76

Jurczyszyn M (2001) Reintroduction of the edible dormouse (Glis glis) in Sierakowski landscape park (Poland). Preliminary results. Trakya Univ J Sci Res Ser B 2:111-114

Jurczyszyn M (2006) The use of space by translocated edible dormice, Glis glis (L.), at the site of their original capture and the site of their release: radio-tracking method applied in a reintroduction experiment. Pol J Ecol 54:345-350

Jurczyszyn M (2018) Food and foraging preferences of the edible dormouse Glis glis at two sites in Poland. Folia Zool 67:83-90. https ://doi.org/10.25225/fozo.v67.i2.a5.2018

Juškaitis R (1997) Ranging and movement of the common dormouse Muscardinus avellanarius in Lithuania. Acta Theriol 42:113-122

Juškaitis R (2005) The influence of high nestbox density on the common dormouse Muscardinus avellanarius population. Acta Theriol 50:43-50. https://doi.org/10.1007/BF03192617

Juškaitis R (2006) Interactions between dormice (Gliridae) and holenesting birds in nestboxes. Folia Zool 55:225-236

Juškaitis R (2007a) Habitat selection in the common dormouse Muscardinus avellanarius (L.) in Lithuania. Baltic For 13:89-95

Juškaitis R (2007b) Feeding by the common dormouse (Muscardinus avellanarius): a review. Acta Zool Lit 17:151-159

Juškaitis R (2008) Long-term common dormouse monitoring: effects of forest management on abundance. Biodivers Conserv 17:35593565. https://doi.org/10.1007/s10531-008-9470-9

Juškaitis R (2018) Dormouse (Gliridae) status in Lithuania and surrounding countries: a review. Folia Zool 67:64-68. https://doi. org/10.25225/fozo.v67.i1.a6.2018

Juškaitis R (2020) Hazel dormice (Muscardinus avellanarius) in a regenerating clearing: the effects of clear-felling and regrowth thinning on long-term abundance dynamics. Eur J Wildl Res 66:48. https://doi.org/10.1007/s10344-020-01392-z

Juškaitis R, Remeisis R (2007a) Summer nest sites of the common dormouse Muscardinus avellanarius $\mathrm{L}$. in young woodlands of Lithuania. Pol J Ecol 55:795

Juškaitis R, Remeisis R (2007b) Harvest mice Micromys minutus and common dormice Muscardinus avellanarius live sympatric in woodland habitat. Acta Theriol 52:349-354. https://doi. org/10.1007/BF03194232

Juškaitis R, Šiožinyte V (2008) Habitat requirements of the common dormouse (Muscardinus avellanarius) and the fat dormouse (Glis glis) in mature mixed forest in Lithuania. Ecol Bratisl 27:143

Juškaitis R, Balčiauskas L, Šiožinytė V (2012) Nest site preference of forest dormouse Dryomys nitedula (Pallas) in the north-western corner of the distribution range. Pol J Ecol 60:815-826
Juškaitis R, Balčiauskas L, Šiožinytė V (2013) Nest site selection by the hazel dormouse Muscardinus avellanarius: is safety more important than food? Zool Stud 52:53. https://doi. org/10.1186/1810-522X-52-53

Juškaitis R, Baltrūnaitė L, Kitrytė N (2016) Feeding in an unpredictable environment: yearly variations in the diet of the hazel dormouse Muscardinus avellanarius. Mam Res 61:367-372. https ://doi.org/10.1007/s13364-016-0280-2

Karantanis N-E, Rychlik L, Herrel A, Youlatos D (2017) Comparing the arboreal gaits of Muscardinus avellanarius and Glis glis (Gliridae, Rodentia): a first quantitative analysis. Mam Study 42:161-172. https://doi.org/10.3106/041.042.0306

Keckel M, Büchner S, Ansorge H (2012) Does the occurrence of the hazel dormouse Muscardinus avellanarius in East-Saxony (Germany) dependent on habitat isolation and size? Peckiana 8:57-60

Kelm J, Lange A, Schulz B, Göttsche M, Steffens T, Reck H (2015) How often does a strictly arboreal mammal voluntarily cross roads? New insights into the behaviour of the hazel dormouse in roadside habitats. J Verteb Biol 64:342-348. https://doi. org/10.25225/fozo.v64.i4.a9.2015

Krofel M, Huber D, Kos I (2011) Diet of Eurasian lynx Lynx lynx in the northern Dinaric mountains (Slovenia and Croatia). Acta Theriol 56:315-322. https://doi.org/10.1007/s13364-011-0032-2

Kryŝtufek B, Vohralik V (1994) Distribution of the forest dormouse Dryomys nitedula (Pallas, 1779) (Rodentia, Myoxidae) in Europe. Mam Rev 24:161-177. https://doi. org/10.1111/j.1365-2907.1994.tb00140.x

Lang J, Büchner S, Ehlers S, Schulz B (2013) Kompensationsmaßnahmen für Haselmäuse im Wald. AFZ Der Wald 10:14-17

Lebl K, Rotter B, Kürbisch K, Bieber C, Ruf T (2011) Local environmental factors affect reproductive investment in female edible dormice. J Mam 92:926-933. https://doi. org/10.1644/10-MAMM-A-225.1

Magomedov M (2015) Assessment of the habitat quality of the forest dormouse (Dryomys nitedula) in Daghestan, Russia: role of foods and vegetation structure. Folia Zool 64:356-360. https:// doi.org/10.25225/fozo.v64.i4.a11.2015

Mänd R, Tilgar V, Lõhmus A, Leivits A (2005) Providing nest boxes for hole-nesting birds - does habitat matter? Biodivers Conserv 14:1823-1840. https://doi.org/10.1007/s10531-004-1039-7

Marchesi L, Sergio F, Pedrini P (2002) Costs and benefits of breeding in human-altered landscapes for the Eagle Owl Bubo bubo. Ibis 144:E164-E177. https://doi.org/10.1046/j.1474-919X.2002. t01-2-00094_2.x

Marchesi L, Sergio F, Pedrini P (2006) Implications of temporal changes in forest dynamics on density, nest-site selection, diet and productivity of Tawny Owls Strix aluco in the Alps. Bird Study 53:310-318. https://doi.org/10.1080/00063650609461447

Marteau M, Sarà M (2015) Habitat preferences of edible dormouse, Glis glis italicus: implications for the management of arboreal mammals in Mediterranean forests. Folia Zool 64:136-150. https ://doi.org/10.25225/fozo.v64.i2.a7.2015

Michaux J, Hürner H, Krystufek B, Sarà M, Ribas A, Cornuet JM, Ruch T, Vekhnik V, Renaud S (2019) Genetic structure of a European forest species, the edible dormouse (Glis glis): consequence of past anthropogenic forest fragmentation? Biol J Linn Soc 126:836-851. https://doi.org/10.1093/biolinnean/bly176

Mikusiński G, Gromadzki M, Chylarecki P (2001) Woodpeckers as indicators of forest bird diversity. Conserv Biol 15:208-217. https://doi.org/10.1046/j.1523-1739.2001.99236.x

Milazzo A, Falletta W, Sara M (2003) Habitat selection of Fat dormouse (Glis glis italicus) in deciduous woodlands of Sicily. Acta Zool Acad Sci Hung 49:117-124

Minato S, Iwabuchi M, Aiba H, Ohtake K, Morris P (2012) Helping (Japanese) Dormice to cross the road. Oryx 46:325-326. https:// doi.org/10.1017/S0030605312000762 
Mitchell-Jones AJ, White I (2009) Using reintroductions to reclaim the lost range of the dormouse, Muscardinus avellanarius, in England. Folia Zool 58:341-348

Mitchell-Jones AJ, Amori G, Bogdanowicz W, Krystufek B, Reijnders PJH, Spitzenberger F, Stubbe M, Thissen JBM, Vohralik V, Zima J (1999) The atlas of European mammals, vol 3. Academic Press, London

Moher D, Liberati A, Tetzlaff J, Altman DG, Group P (2009) Preferred reporting items for systematic reviews and meta-analyses: the PRISMA statement. PLoS Med 6:e1000097. https://doi. org/10.1371/journal.pmed.1000097

Moreno S, Rouco C (2013) Responses of a small-mammal community to habitat management through controlled burning in a protected Mediterranean area. Acta Oecol 49:1-4. https://doi. org/10.1016/j.actao.2013.02.001

Mortelliti A, Sanzo GS, Boitani L (2009) Species'surrogacy for conservation planning: caveats from comparing the response of three arboreal rodents to habitat loss and fragmentation. Biodivers Conserv 18:1131-1145. https://doi.org/10.1007/s1053 1-008-9477-2

Mortelliti A, Amori G, Capizzi D, Cervone C, Fagiani S, Pollini B, Boitani L (2011) Independent effects of habitat loss, habitat fragmentation and structural connectivity on the distribution of two arboreal rodents. J Appl Ecol 48:153-162. https://doi.org/10.11 11/j.1365-2664.2010.01918.x

Mortelliti A, Santarelli L, Sozio G, Fagiani S, Boitani L (2013) Long distance field crossings by hazel dormice (Muscardinus avellanarius) in fragmented landscapes. Mam Biol 78:309-312. https ://doi.org/10.1016/j.mambio.2012.09.006

Mortelliti A, Sozio G, Driscoll DA, Bani L, Boitani L, Lindenmayer DB (2014) Population and individual-scale responses to patch size, isolation and quality in the hazel dormouse. Ecosphere 5:1-21. https://doi.org/10.1890/ES14-00115.1

Moska M, Mucha A, Wierzbicki H (2018) Genetic differentiation of the edible dormouse (Glis glis) in the Polish Sudetens: the current status of an endangered species. J Zool 305:203-211. https://doi. org/10.1111/jzo.12552

Naim DM, Telfer S, Tatman S, Bird S, Kemp SJ, Hughes R, Watts PC (2012) Patterns of genetic divergence among populations of the common dormouse, Muscardinus avellanarius in the UK. Mol Biol Rep 39:1205-1215. https://doi.org/10.1007/s1103 3-011-0850-y

Naim DM, Telfer S, Tatman S, Bird S, Kemp SJ, Watts PC (2014) Movement patterns and genetic diversity of wild and reintroduced common dormice, Muscardinus avellanarius. Genet Mol Res 13:167-181. https://doi.org/10.4238/2014.January.10.8

Nakamura-Kojo Y, Kojo N, Ootsuka T, Minami M, Tamate HB (2014) Influence of tree resources on nest box use by the Japanese dormouse Glirulus japonicus. Mam Study 39:17-26. https://doi. org/10.3106/041.039.0104

Navarro LM, Pereira HM (2015) Towards a European policy for rewilding. Rewilding Eur Landsc 205

Nedyalkov N, Popgeorgiev G, Staneva A (2018) Updated distribution of the elusive Roach's mouse-tailed dormouse, Муотіmиs roachi Bate, 1937 (Mammalia: Rodentia: Gliridae) in Bulgaria. Hist Nat Bulg 29:3-8

Obuch J, Danko Š, Mihók J, Karaska D, Šimák L (2013) Diet of the Ural owl (Strix uralensis) in Slovakia. Raptor J 7:59-71. https:// doi.org/10.2478/srj-2013-0003

Orlov VN, Krivonogov DM, Cherepanova EV, Sazanova OG, Dmitriev AI (2013) Extensive distribution decline of the garden dormouse (Eliomys quercinus) and the probability of losing the intraspecific taxonomic diversity. Zool Zhurnal 92:1349-1358. https:// doi.org/10.7868/S004451341311010X

Panchetti F, Sorace A, Amori G, Carpaneto GM (2007) Nest site preference of common dormouse (Muscardinus avellanarius) in two different habitat types of central Italy. Ital J Zool 74:363-369. https://doi.org/10.1080/11250000701588224

Perry RW, Jenkins JM, Thill RE, Thompson FR III (2018) Long-term effects of different forest regeneration methods on mature forest birds. For Ecol Manag 408:183-194. https://doi.org/10.1016/j. foreco.2011.05.002

Peshev C, Peshev D, Popov V (2004) Fauna Bulgarica, vol 27. Mammalia, BAS, Sofia ([In Bulgarian with English summary])

Pilāts V, Pilāte D, Ornicāns A, Kārkliṇš A (2012) Microhabitat utilization by forest dormice (Dryomys nitedula) in boreo-nemoral forest-preliminary results. Peckiana 8:77-85

Ramakers JJ, Dorenbosch M, Foppen RP (2014) Surviving on the edge: a conservation-oriented habitat analysis and forest edge manipulation for the hazel dormouse in the Netherlands. Eur J Wildl Res 60:927-931. https://doi.org/10.1007/s10344-014-0849-5

Ruf T, Fietz J, Schlund W, Bieber C (2006) High survival in poor years: life history tactics adapted to mast seeding in the edible dormouse. Ecology 87:372-381. https://doi.org/10.1890/05-0672

Sarà M, Milazzo A, Falletta W, Bellia E (2005) Exploitation competition between hole-nesters (Muscardinus avellanarius, Mammalia and Parus caeruleus, Aves) in Mediterranean woodlands. J Zool 265:347-357. https://doi.org/10.1017/S095283690500645X

Scaravelli D, Bassi S (1994) Myoxus glis as a cave dwelling animal. Hystrix 6:283-285. https://doi.org/10.4404/hystrix-6.1-2-4041

Schickmann S, Urban A, Kräutler K, Nopp-Mayr U, Hackländer K (2012) The interrelationship of mycophagous small mammals and ectomycorrhizal fungi in primeval, disturbed and managed Central European mountainous forests. Oecologia 170:395-409. https://doi.org/10.1007/s00442-012-2303-2

Ściński M, Borowski Z (2006) Home ranges, nest sites and population dynamics of the forest dormouse Dryomys nitedula pallas in an oak hornbeam forest: a live trapping and radio tracking study. Pol J Ecol 54:391-396

Shibata F, Kawamichi T, Nishibayashi K (2004) Daily rest-site selection and use by the Japanese dormouse. J Mam 85:30-37. https ://doi.org/10.1644/BPR-007

Sozio G, Iannarilli F, Melcore I, Boschetti M, Fipaldini D, Luciani M, Roviani D, Schiavano A, Mortelliti A (2016) Forest management affects individual and population parameters of the hazel dormouse Muscardinus avellanarius. Mam Biol 81:96-103. https ://doi.org/10.1016/j.mambio.2014.12.006

Trout RC, Brooks SE, Rudlin P, Neil J (2012) The effects of restoring a conifer plantation on an ancient woodland site (PAWS) in the UK on the habitat and local population of the Hazel Dormouse (Muscardinus avellanarius). Eur J Wildl Res 58:635-643. https ://doi.org/10.1007/s 10344-012-0611-9

Trout RC, Brooks S, Combe FJ, Rudlin P (2018) The different effects of periodic experimental tree removal patterns on the population demography of the hazel dormice (Muscardinus avellanarius) in a conifer plantation. Folia Zool 67:110-119. https://doi. org/10.25225/fozo.v67.i2.a7.2018

Tscharntke T, Clough Y, Wanger TC, Jackson L, Motzke I, Perfecto I, Vandermeer J, Whitbread A (2012) Global food security, biodiversity conservation and the future of agricultural intensification. Biol Conserv 151:53-59. https://doi.org/10.1016/j.bioco n.2012.01.068

Vekhnik VA (2019) Effect of food availability on the reproduction in edible dormice (Glis glis L., 1766) on the eastern periphery of the range. Mam Res 64:423-434. https://doi.org/10.1007/s1336 4-019-00425-6

Verbeylen G (2006) Status and conservation of the common dormouse (Muscardinus avellanarius) in the province of Limburg (Flanders, Belgium). Lutra 49:75-88

White IC, Hughes SA (2019) Trial of a bridge for reconnecting fragmented arboreal habitat for hazel dormouse Muscardinus 
avellanarius at briddlesford nature reserve, isle of wight. UK Conserv Evid 16:6-11

Williams RL, Goodenough AE, Hart AG, Stafford R (2013) Using long-term volunteer records to examine dormouse (Muscardinus avellanarius) nestbox selection. PLoS ONE 8(6):e67986. https ://doi.org/10.1371/journal.pone.0067986

Wolton R (2009) Hazel dormouse Muscardinus avellanarius (L.) nest site selection in hedgerows. Mammalia 73:7-12. https://doi. org/10.1515/MAMM.2009.001

Youlatos D, Karantanis NE, Byron CD, Panyutina A (2015) Pedal grasping in an arboreal rodent relates to above-branch behavior on slender substrates. J Zool 296:239-248. https://doi. org/10.1111/jzo.12237
Zapponi L, Del Bianco M, Luiselli L, Catorci A, Bologna MA (2013) Assessing environmental requirements effects on forest fragmentation sensitivity in two arboreal rodents. Mam Biol 78:157-163. https://doi.org/10.1016/j.mambio.2012.08.005

Publisher's Note Springer Nature remains neutral with regard to jurisdictional claims in published maps and institutional affiliations. 